\title{
Tesis Summary
}

Latif A.A., Abdul (111214253012). Kesejahteraan Psikologis Masyarakat Miskin Penerima Bantuan RRTLH di Kabupaten Sidoarjo. Tesis. Fakultas Psikologi Universitas Airlangga Surabaya.

xiv+108 halaman, 3 lampiran

Penelitian ini bertujuan untuk mengeksplorasi konsep kesejahteraan psikologis yang berhubungan dengan program bantuan rehab rumah tidak layak huni (RRTLH) di Kabupaten Sidoarjo. Dalam penelitian ini secara khusus mengetengahkan untuk memahami dinamika kesejahteraan psikologis pada masyarakat miskin yang menerima program bantuan RRTLH. Pada banyak penelitian sebelumnya ditegaskan bahwa rumah yang tidak layak dapat berpengaruh dan berkontribusi pada tingkat kesejahteraan psikologis. Dalam penelitian ini, bagaimana bantuan rehab rumah dapat memberikan gambaran proses perubahan kesejahteraan psikologis pada masyarakat miskin dengan rumah tidak layak.

Menggunakan pendekatan penelitian grounded theory, diharapkan dalam penelitian diperoleh deskripsi atau gambaran preposisi-preposisi tentang proses perubahan kesejahteraan psikologis pada penerima rehab rumah. Data diperoleh dengan melakukan wawancara dengan 13 informan penerima bantuan rehab rumah tidak layak huni yang dipilih secara acak. Data wawancara dianalisis dan dikelompokkan ke dalam kategori, sub-tema, dan tema yang saling berhubungan satu sama lain.

Dari proses penelitian dan analisis data bahwa perubahan kesejahteraan psikologis setelah mendapatkan bantuan rehab rumah digambarkan dengan (1) hadirnya semangat dan tekad untuk melanjutkan perbaikan setelah mendapatkan bantuan rehab rumah, (2) keputusan yang realistis dengan tetap memprioritas pendidikan anak dibandingkan melanjutkan rehab rumah, dan (3) penerimaan diri dengan kondisi yang ada sekarang. Selanjutnya, proses perubahan kesejahteraan psikologis merupakan serangkaian preposisi-preposisi yang saling berhubungan. Kesejahteraan psikologis yang berhubungan dengan kebijakan dan pemberian bantuan rehab rumah dipengaruhi faktor psikologis dari konsep diri, persepsi terhadap bantuan kemiskinan, dan harapan tentang rumah layak huni.

Kata Kunci: Kesejahteraan Psikologis, Bantuan Rehab Rumah (RRTLH) 


\section{BAB 5 \\ SIMPULAN DAN SARAN}

\subsection{Kesimpulan}

Dalam kajian psikologi sosial, kemiskinan tidak dapat dipahami sebatas fakta sosial yang menimpa individu sebagai ketercerabutan (deprivasi) pada akses kebutuhan dasar. Lebih dari itu baik miskin maupun kemiskinan melekat dan dilekatkan pada individu melalui serangkaian proses kognitif dan perasaan dalam proses interaksi sosial sehari-hari. Dalam hal deprivasi pada kebutuhan rumah layak, program bantuan rehab rumah dapat dilihat pada sebatas tanggungjawab pemerintah dalam memberikan jaminan kesejahteraan sosial pada masyarakat miskin yang karena satu alasan tertentu tidak mampu memenuhi domain kebutuhan rumah layak.

Berbeda dengan penekatan psikologi sosial, kemiskian dilihat sebagai sebagai setting sosial dimana individu mengorganisasi makna-makna yang berhubungan dengan kemiskinan tersebut dan bertindak berdasarkan pada makna-makna tersebut. Jika bantuan RRTLH pemerintah Kabupaten Sidoarjo disebut sebagai bantuan stimulan, tentu perubahan sikap menjadi dampak yang diharapkan dari penerima bantuan tersebut. Rumah dalam hierarki kebutuhan Maslow dalam penelitian ini dapat masuk sekaligus sebagai kebutuhan dasar, rasa aman dan identitas sosial (self esstem) dan puncak dari hierarki kebutuhan Maslow adalah aktualisasi diri yang menjadi dasar pemikiran dari tercapainya kesejahteraan psikologi.

Kepemilikan rumah tidak layak menjadi asumsi dasar yang dapat mereduksi makna kesejahteraan psikologis, sehingga bagaimana masyarakat memaknai pemberian bantuan rehab rumah pada akhirnya memberikan gambaran pergeseran makna kesejahteraan psikologis, khususnya yang berhubungan dengan stimulasi batuan rehab rumah. Dalam penelitian ini beberapa temuan grounded yang berhubungan dengan rumah diperoleh dari penerima rehab rumah sebagai berikut:

1. Pertama, masyarakat penerima bantuan rehab rumah memiliki beberapa makna rumah yang juga menjadi identifikasi harapan atas rumah layak 
yang ingin dicapainya. Rumah memiliki makna yang menegaskan fungsi fisik sebagai tempat tinggal dan berteduh (panggonan), dan ketiadaan rumah digambarkan dengan kondisi yang tidak nyaman. Perasaan nyaman dan menegaskan kemadirian merupakan fungsi secara psikologis rumah sebagai pengayoman. Selain itu rumah juga menjadi identitas sosial sebagai bagian dari masyarakat yang dapat menjadi sumber hadirnya harga diri (self esteem).

2. Kedua, refleksi dinamika psikologis sebelum dan setelah mendapatkan bantua rehab rumah. Secara umum dinamika psikologis merefleksikan dari dinamika emosi (sumpek, kruntelan, awas dan tidak nyaman), rendah diri (malu, minder dan isolasi) serta penilaian diri negatif seperti perasaan tidak mampu. Beberapa makna perubahan setelahnya juga memberikan gambaran perubahan dinamika psikologis meningkatnya harga diri, emosi yang psoitif dan penilaian diri yang positif.

3. Ketiga, untuk memperoleh makna dari sikap yang merefleksikan makna kesejahteraan psikologis dalam hubungannya dengan bantuan rehab rumah, makna kesejateraan psikologis hadir dari pemaknaan penerima bantuan terhadap bantuan yang membimbing tingkah laku partispasi. Kesejahteraan psikologis ditunjukkan dengan persepsi yang positif pada bantuan sehingga menjadi lebih bersemangan dan memiliki keberanian untuk membangun rumah. Namun makna kesejahteraan psikologis tidak semerta langsung berhubungan dengan rumah, namun juga dalam bentuk keputusan realistis dengan memprioritaskan pendidikan anak dibandingkan rumah. Selain itu, kepemilikan rumah yang dikatakan layak juga mempengauhi tingkat partisipasi pada kegiatan di lingkungannya.

4. Secara garis besar kesejahteraan psikologis pada masyarakat penerima bantuan rehab rumah yaitu: (a) dalam bentuk persepsi yang positif tentang diri yang berhubungan dengan bantuan rehab rumah sebagai stimulan, (b) semangat dan rencana pengembangan setelah program bantuan selesai, (c) pengambilan keputusan yang realistis pada domain kebutuah lain seperti dengan mengutamakan domain pendidikan 
daripada melanjutkan perbaikan rumah (c) parasaan dapat berpartispasi sosial dengan baik, dan (c) pada kelompok usia lansia cendrung dengan menerima keadaan yang sudah ada dengan rasionalisasi usia yang sudah tua.

Dalam penelitian ini juga tidak dapat dipungkiri terdapatnya pemaknaan dan sikap diri yang cenderung akan mereduksi makna kesejahteraan psikologis itu sendiri, seperti menegaskan perasaan tidak mampu, kembali mengharapkan bantuan dan persepsi negatif pada jumlah bantuan yang terbatas.

Pergeseran kesejahteraan psikologis yang berhubungan dengan bantuan rehab rumah sebagaimana disampaikan diatas tidak kemudian menjadi kesimpulan bahwa dengan memberikan bantuan rehab rumah maka terdapat kecenderungan perubahan kesejahteraan psikologis meningkat. Beberapa faktor yang meliputi persepsi diri, persepsi tentang bantuan, gambaran rumah layak yang diharapkan atau yang dapat disebut dengan faktor internal individu memberikan pengaruh dominan padakesejahteraan psikologis. Faktor-faktor ini mengarahkan pada sikap dan tindakan yang mengambarkan kesejahteraan psikologis seperti semangat untuk mengembangkan dalam bentuk perencanaan.

\subsection{Saran}

1.2.1. Bagi peneliti selanjutnya

Pada dasarnya dalam penelitian ini merupakan ketertarikan bagaimana individu yang berada dalam deprivasi rumah layak dan kemudian mendapatkan bantuan rumah layak memaknai kondisi yang mereka hadapi serta bertindak dengan makna-makna tersebut. Pergeseran dan pemaknaan yang positif jelas merefleksikan terdapatnya makna kesejahteraan psikologis dari bantuan stimulasi rehab rumah.

Luasnya domain kajian kesejahteraan psikologis dalam paradigma kajian psikologi sosial mengharuskan peneliti untuk lebih teliti dalam memilih tema. Hal ini karena kompleknya tema psikologi yang menjadi penentu hadirnya kesejahteraan psikologis. Kunci jawaban dari kesejahteraan psikologis terletak pada makna-makna yang selanjutnya dapat menjadi konsep diri positif. Penelitian ini masih melihat domain umum bentuk 
kesejahteraan psikologis. Bagi penelitian selanjutnya, pendekatan entografi dalam meneliti kesejahteraan psikologi akan dapat memberikan komplek kesejahteraan psikologis dalam seting kebudayaan akan dapat jauh lebih memberikan pemahaman mendasar dari sisi individu memaknai realitas dan kondisi kemiskinan dalam hubungannya antara kapasitas individu sebagai pribadi yang unik, namun juga menyerap nilai sebagai bagian dari pembudayaan.

\subsubsection{Bagi praktisi penanggulangan kemiskinan}

Ironis ketika melihat bantuan yang tujuannya untuk mengeluarkan individu dari kemiskinan justru menjadikan individu ketergantungan. Banyak hal yang dapat dikritisi dari program penanggulangan kemiskinan di Indonesia dari sudut pandang psikologi, salah satu diantara pelabelan miskin pada sekelompok orang tertentu justru pada akhirnya dapat membimbing individu untuk memerankan status sosial tersebut. Seringnya kegagalan resilien pada masyarakat miskin penerima bantuan lebih karena persepsi negatif dan kegagalan memaknai bersama bantuan sebagai stimulan.

Dalam program bantuan penanggulangan kemiskinan yang bersifat stimulan, keberlanjutan untuk melanjutkan yang berangkat dari dalam penerima bantuan merupakan keharusan. Mengupayakan pemberian bantuan karitas untuk memberikan akses rumah layak huni sudah sepatutnya menjadi tanggungjawab pemerintah. Namun, evaluasi pada batas mana tingkat partisipasi penerima bantuan dan faktor apa saja yang mempengaruhi tingkat partispasi menjadi hal yang penting untuk efektifnya bantuan. Praktisi dalam penanggulangan kemiskinan selanjutnya mesti dapat melihat bagaimana faktor psikologis dan seberapa jauh mempengaruhi tingkat partisipasi, sehingga dapat menentukan strategi yang tepat karena faktor-faktor tersebut. 